\title{
Impact of fine litter chemistry on lignocellulolytic enzyme efficiency during decomposition of maize leaf and root in soil
}

\author{
Bilal Ahmad Zafar Amin • Brigitte Chabbert • \\ Daryl Moorhead · Isabelle Bertrand
}

Received: 12 October 2012/Accepted: 22 April 2013/Published online: 7 May 2013

(C) The Author(s) 2013. This article is published with open access at Springerlink.com

\begin{abstract}
Residue recalcitrance controls decomposition and soil organic matter turnover. We hypothesized that the complexity of the cell wall network regulates enzyme production, activity and access to polysaccharides. Enzyme efficiency, defined as the relationship between cumulative litter decomposition and enzyme activities over time, was used to relate these concepts. The impact of two contrasting types of cell walls on xylanase, cellulase and laccase efficiencies was assessed in relation to the corresponding changes in residue chemical composition (xylan, glucan, lignin) during a 43-day incubation period. The selected residues were
\end{abstract}

Electronic supplementary material The online version of this article (doi:10.1007/s10533-013-9856-y) contains supplementary material, which is available to authorized users.

B. A. Z. Amin - B. Chabbert · D. Moorhead - I. Bertrand INRA,UMR 614 Fractionnement des AgroRessources et Environnement, 51100 Reims, France

B. A. Z. Amin - B. Chabbert - I. Bertrand Université de Reims Champagne-Ardenne, UMR614 Fractionnement des AgroRessources et Environnement, 51100 Reims, France

D. Moorhead

Department of Environmental Science, University

of Toledo, Toledo, $\mathrm{OH} 43606$, USA

I. Bertrand $(\bowtie)$

INRA, CREA, 2 esplanade Roland Garros,

51686 Reims Cedex 2, France

e-mail: Isabelle.bertrand@ reims.inra.fr maize roots, which are rich in secondary cell walls that contain lignin and covalent bridges between heteroxylans and lignin, and maize leaves having mostly nonlignified primary cell walls thus making the cellulose and hemicelluloses less resistant to enzymes. Relationships between $\mathrm{C}$ mineralization and change in residue quality through decomposition indicated that the level of substitution of arabinoxylans (arabinan to xylan ratio) provides a good explanation of the decomposition process. In leaves enriched in primary cell walls, arabinose substitution of xylan controlled $\mathrm{C}$ mineralization rate but hampered polysaccharide decomposition, but to a lesser extent than in roots in which arabinoxylans were mostly cross-linked with lignin. Enzyme activity was higher in leaf than root amended soils while enzyme efficiency was systematically higher in the presence of roots. This apparent paradox suggests that residue quality could preselect the microbial community. Indeed, we found that microorganisms exhibited an initial rapid growth in the presence of a high quality litter and produced enzymes that are not efficient in degrading recalcitrant cell walls while, in the presence of the more recalcitrant maize roots, microbial biomass grew more slowly but produced enzymes of higher efficiency. This high enzyme efficiency could be explained by the synergistic action of hydrolytic and oxidative enzymes even in the early stage of decomposition.

Keywords Decomposition - Enzymes · Litter quality $\cdot$ Soil organic matter $\cdot \mathrm{C}$ cycle 


\section{Introduction}

The decomposition of plant residues is a process of crucial global importance (Sinsabaugh et al. 2002) and residue quality is a key factor determining decomposition patterns and related nutrient cycling (Heal et al. 1997). Plant residues consist of a soluble and an insoluble fraction (cell wall), which vary by species, tissue type and maturity. Cell walls consist mainly of insoluble polymers such as cellulose, hemicelluloses and lignin, which form a complex, chemical network that influences biological degradation (Chesson 1988, 1997; Bertrand et al. 2006; Šnajdr et al. 2011). The recalcitrance of residues to decomposition is mainly related to cell wall polymer content, i.e., lignin (Melillo et al. 1982; Berg and McClaugherty 2008). Recently, finer scale residue chemical characteristics related to hemicellulose substitution level (i.e., arabinose to xylose ratio), and interactions between cellulose, hemicellulose and lignin have provided new insights to chemical controls on decomposition (Machinet et al. 2009, 2011a). These studies demonstrated that $\mathrm{C}$ mineralization of maize roots in soil was described by both cell wall polymer content, cross linking agents (hydroxycinnamic acids) between hemicellulose and lignin, and the substitution level of hemicelluloses. In Gramineae, hemicelluloses are the main non-cellulosic polysaccharides and form a backbone of $\beta-1,4$-linked xylose units mainly substituted by $\alpha$-linked arabinose on C- 2 or C-3 positions apart from acetyl and glucuronic branching (Brett and Waldron 1996). These arabinose substitutions can be esterified by ferulic acid (FA) and form diferulate bridges and ether linkages with lignin, thereby crosslinking arabinoxylan chains and arabinoxylan/lignin connections, respectively. The presence of lignin and cross-linking phenolic acids is well known to regulate enzyme access to cellulose and hemicelluloses in forage digestibility and bioreffinery studies (Chesson 1988, 1997; Lam et al. 2003; Berlin et al. 2006) and appears to affect decomposition in soils (Machinet et al. 2009, 2011a; Talbot et al. 2012).

Extracellular enzymes are the main agents responsible for residue biodegradation in soil and their patterns of activity are commonly used to explain changes in residue quality during decomposition (Sinsabaugh et al. 2002; Allison and Vitousek 2004; Šnajdr et al. 2011). However, in natural environments such as soils, enzyme activity may not always reflect enzyme efficiency. Indeed, enzyme efficiency is defined as the relationship between litter decomposition, i.e. mass loss or $\mathrm{C}$ mineralized, and enzyme activities over time (Sinsabaugh et al. 2002). Therefore enzyme efficiency in soils is influenced by several factors such as accessibility to substrate, non-specific interactions with minerals or substrates, and production of iso-enzymes by different microorganisms etc., which make the determination of enzyme catalytic activity and kinetic characteristics difficult (Nannipieri and Gianfreda 1998). Recently the study by Wang et al. (2012) noted that enzyme kinetic parameters measured under field conditions were an order of magnitude (or more) less than in pure cultures. Thus, measured activity must be linked to measured decomposition criteria to establish enzyme efficiency in situ.

In soils, microorganisms are continuously producing enzymes so that substrate cell wall polymer structure and accessibility may be the rate-limiting step regulating nutrient acquisition. Indeed, Voriskova et al. (2011) demonstrated that litter quality impacts growth and enzyme production by a saprotrophic basidiomycete and underscored the role of cellobiohydrolase, which catalyses the rate limiting step of cellulose decomposition. However, most of these studies are based on relationships established between litter mass loss and measured enzyme activities and do not take into account the changes in specific substrates catalyzed by the enzyme of interest nor the complexity of cell walls that hinders substrate degradation (Himmel 2007). In addition most studies addressing the drivers of changes in litter chemistry during decomposition and relationships with enzyme efficiency were performed in situ using litterbags and acknowledge that factors such as soil type, climate or $\mathrm{N}$ availability might interfere (Sinsabaugh et al. 2002; Wickings et al. 2012). An important challenge for understanding and modeling litter decomposition is thus to link enzyme production, activity and turnover to litter quality evolution (Schimel and Weintraub 2003; Allison 2005; Moorhead et al. 2012). Given the difficulties of measuring enzyme parameters in soils, we propose using enzyme efficiency to evaluate the link between litter structural chemistry and lignocellulolytic enzyme activity.

Our objective was to measure the impact of residue cell wall quality on enzyme efficiency during decomposition in soil. To do so we selected two contrasting types of cell walls: (i) maize roots, which are rich in 
(a)

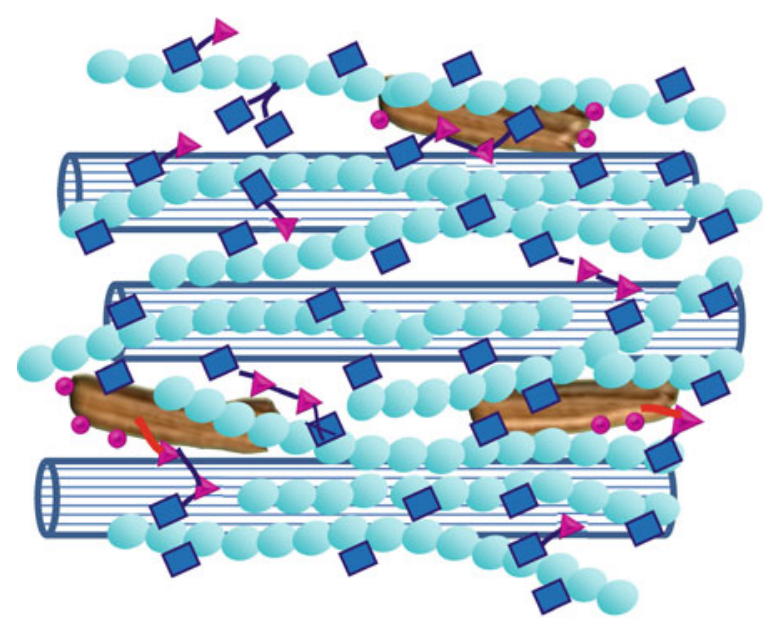

(b)

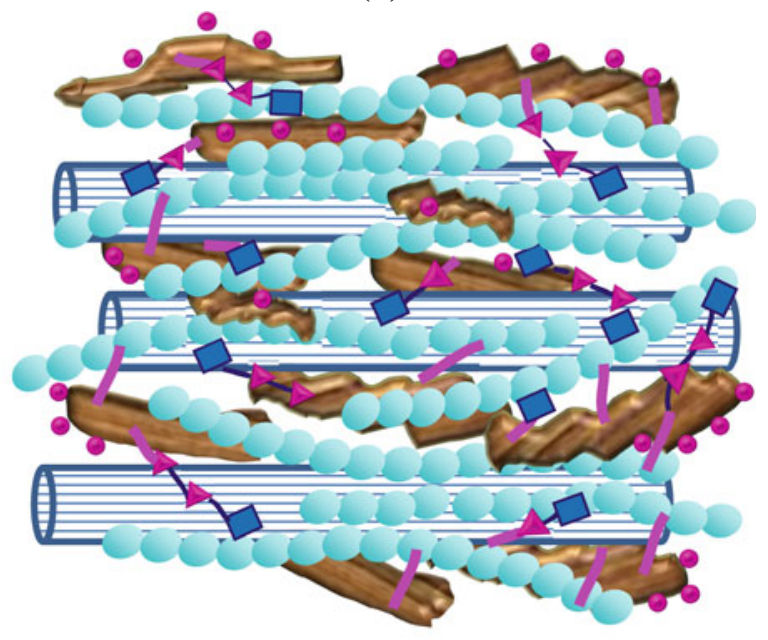

Covalent linkage between

lignin and hemicellulose

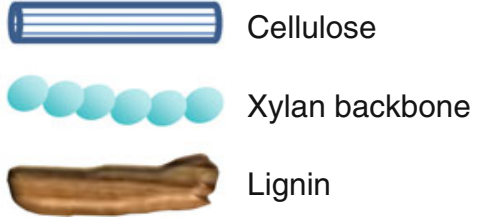

Fig. 1 Schematic representation of maize cell walls. a Weakly lignified primary cell walls contain highly substituted arabinoxylans. b Lignified secondary cell walls contain less substituted arabinoxylan which are covalently linked to lignin.

secondary cell walls (Fig. 1b) that contain lignin and covalent FA bridges between heteroxylan backbones and the ester-ether bridges between the heteroxylans and lignin (Machinet et al. 2011a) and (ii) maize leaves, which are less rich in cell walls and these being mostly low-lignified primary cell walls (Fig. 1a) with less hydroxycinnamic acid, making the cellulose and hemicellulose less resistant to enzymes (Huyen et al. 2010). To measure enzyme efficiency on maize leaf and root cell walls, we measured the main lignocellulolytic enzyme activities (xylanase, cellulase and laccase), the corresponding changes in the chemical composition of the residue, i.e., xylan glucan and lignin, and $\mathrm{C}$ mineralization during a 43-day incubation period.

\section{Materials and methods}

Soil sampling and preparation

The soil used was a Luvisol Orthique (FAO classification), a Typic Hapludalf (USDA classification) from
Phenolic acid, as mostly ferulic acid, mainly cross links arabinoxylan chains in primary cell walls, and arabinoxylan and lignin in secondary cell walls

northeast France $\left(49^{\circ} 80^{\prime} \mathrm{N}, 3^{\circ} 60^{\prime} \mathrm{E}\right)$. It contains $16.8 \%$ clay, $76.3 \%$ silt and $3.8 \%$ sand, has an organic carbon content of $8.70 \mathrm{mg} \mathrm{C} \mathrm{g}^{-1}$ and a $\mathrm{pH}$ (soil $\mathrm{H}_{2} \mathrm{O}$ ) of 7.6 (Bertrand et al. 2006). Soil was collected in autumn 2008 from 10 soil cores to a depth of $0-30 \mathrm{~cm}$, then pooled and air-dried for 2 days to reduce moisture content to $120 \mathrm{mg}$ water $\mathrm{g}^{-1}$ dry soil. Fresh soil samples were sieved to $2 \mathrm{~mm}$ then cleaned manually to remove crop residues. The soil was stored at $4{ }^{\circ} \mathrm{C}$ to reduce microbial activity.

\section{Plant residues}

The maize (Zea mays L.) cultivar, Mexxal, was grown at the INRA Lusignan experimental station $\left(49^{\circ} 26^{\prime} \mathrm{N}\right.$, $0^{\circ} 07^{\prime} \mathrm{E}$, Vienne, France) and harvested at physiological maturity at the end of September 2008. The leaves were removed from the stover and cut into fragments of about $0.5 \mathrm{~cm}$ length $\times 0.5 \mathrm{~cm}$ width. Roots of 3-5 $\mathrm{mm}$ in diameter were selected and cut into fragments of $1 \mathrm{~cm}$ length. These leaf and root pieces were stored in the dark and dried at $35{ }^{\circ} \mathrm{C}$ for a week 
prior to being used for incubation experiments and analysis.

\section{Incubation experiment}

Incubation experiments were performed for 43 days at $15 \pm 0.5^{\circ} \mathrm{C}$ by mixing maize leaves and roots separately with soil (equivalent to $50 \mathrm{~g}$ dry soil) at rates equivalent to $2 \mathrm{~g} \mathrm{C} \mathrm{kg}^{-1}$ dry soil in $250 \mathrm{ml}$ glass jars. Potassium nitrate $\left(61 \mathrm{mg} \mathrm{N} \mathrm{kg}^{-1}\right)$ was added to the initial soil $\mathrm{N}$ concentration of $9 \mathrm{mg} \mathrm{N}-\mathrm{NO}_{3} \mathrm{~kg}^{-1}$ (no ammonium was detected) to ensure that decomposition would not be N-limited (Sall et al. 2007). The concentration of added $\mathrm{N}$ solution was such that the soil moisture remained at a potential of $-80 \mathrm{kPa}$, corresponding to $190 \mathrm{~g} \mathrm{~kg}^{-1}$ air-dried-soil water content. Controls were conducted in the same way without added maize residues. Soil moisture was maintained throughout the incubation period, by weighing weekly and readjusting with deionized water when necessary.

Carbon mineralization was measured in soil samples incubated in glass jars in the presence of a $\mathrm{CO}_{2}$ trap $(10 \mathrm{ml}$ of $1 \mathrm{M} \mathrm{NaOH})$ at $8,14,21,28,35$ and 43 days after the start of incubation. Carbon dioxide from each of the leaf, root and control treatments was measured using 4 replicates per sampling date. The concentrations of $\mathrm{CO}_{2}$ trapped in the $\mathrm{NaOH}$ solutions were measured by continuous auto-analyzer (TRAACS 2000, Bran and Luebbe).

Two replicates of incubating jars were used to determine the evolution of chemical quality, enzyme activities and biomass $\mathrm{C}$ of maize leaves and roots at each sampling date. Analyses were performed at day 0 which corresponds to residues that were mixed with soil and then removed within $10 \mathrm{~min}$, and after 8, 14, $21,28,35$ and 43 days of incubation. For residue chemical analysis at each date, residue was removed manually from the soil and gently brushed to remove soil particles from the residue surface.

\section{Chemical analysis of maize residues}

At day 0 , total $\mathrm{C}$ and $\mathrm{N}$ contents of leaves and roots were measured by elemental analysis (NA 2000, Fisons Instruments, Milan, Italy). The soluble and cell wall contents of leaf and root residues were determined by neutral detergent fiber (NDF) extraction, according to the method described by Goering and Van Soest (1970).

At day 0 and during incubation, polysaccharide analyzes were performed as previously described (Machinet et al. 2011a). Ten $\mathrm{mg}$ of residue was placed to swell in $125 \mu \mathrm{l} 12 \mathrm{M} \mathrm{H}_{2} \mathrm{SO}_{4}$ for $2 \mathrm{~h}$ at $20{ }^{\circ} \mathrm{C}$ then subjected to acid hydrolysis with $1 \mathrm{M} \mathrm{H}_{2} \mathrm{SO}_{4}$ for $2 \mathrm{~h}$ at $100{ }^{\circ} \mathrm{C}$. Monosaccharides released by the acid were separated by high performance anion-exchange chromatography (HPAEC) on a CarboPac PA-1 column $\left(4 \times 250 \mathrm{~mm}^{2}\right.$, Dionex, Sunnyvale, CA, USA). Monosaccharide composition was analyzed and quantified using 2-deoxy-D-ribose as internal standard and standard solutions of neutral carbohydrates (L-arabinose, D-glucose, D-xylose, D-galactose, L-rhamnose, D-mannose, L-fucose and D-fructose). The lignin content of residues was approximated as the acidunhydrolyzable residue remaining after sulphuric acid hydrolysis according to the Klason lignin determination (Monties 1984). Acid-unhydrolyzable residue was termed KL-Lignin thereafter. Briefly, $50 \mathrm{mg}$ of residues were suspended in $0.5 \mathrm{ml}$ of $12 \mathrm{M} \mathrm{H}_{2} \mathrm{SO}_{4}$ for $2 \mathrm{~h}$ at room temperature. The suspensions were then diluted to $1 \mathrm{M}$ with deionized water, heated at $100{ }^{\circ} \mathrm{C}$ for $3 \mathrm{~h}$ and filtered. The remaining residues were dried at $105^{\circ} \mathrm{C}$ and ash content determined after $4 \mathrm{~h}$ combustion at $500{ }^{\circ} \mathrm{C}$. Acid-unhydrolyzable residue (KL-Lignin) content was calculated as the mass difference before and after combustion.

For initial characterization (day 0) total hydroxycinnamic acids ( $p$-coumaric and ferulic acids) of maize roots and leaves were released by alkaline hydrolysis. Total amounts of hydroxycinnamic acids were determined by loading Teflon-lined bombs with $10 \mathrm{mg}$ samples and $4 \mathrm{M} \mathrm{NaOH}(15 \mathrm{ml})$. After heating for $2 \mathrm{~h}$ at $170{ }^{\circ} \mathrm{C}$, the bombs were cooled at room temperature for $2 \mathrm{~h}$. The reaction mixture was then acidified to $\mathrm{pH}$ 1-2 with $6 \mathrm{M} \mathrm{HCl}$, before adding 3,4,5, trimethoxytrans-cinnamic acid and ethylvanillin as internal standards (Ilyama et al. 1990). The hydroxycinnamic acids were then extracted three times with diethyl oxide $(25 \mathrm{ml})$. The organic fractions were pooled and evaporated to dryness under reduced pressure. The dried extracts were dissolved in $1.5 \mathrm{ml}$ methanol:water $(1: 1, \mathrm{v} / \mathrm{v})$ and filtered $(0.45 \mu \mathrm{m})$ prior to injection into a Spherisorb S5ODS2 (Waters, RP-18, $250 \times 2.6 \mathrm{~mm}^{2}$ ) column. The elution gradient was: A (acetonitrile, orthophosphoric acid $15 \mathrm{mM}$ in Milli-Q water, 10:90, v/v) 100-92\% for $6 \mathrm{~min}$; then 92-0\% A with solvents 
B (methanol; orthophosphoric acid $15 \mathrm{mM}$ in Milli-Q water, 80:20, v/v 0-50\%) and C (acetonitrile; orthophosphoric acid $15 \mathrm{mM}$ in Milli-Q water, 80:20, v/v) 0-50 \% for $29 \mathrm{~min}$. The hydroxycinnamic acids in the eluates were detected using a waters photodiode array UV detector. Hydroxycinnamic monomers were quantified at $302 \mathrm{~nm}$ using commercial standards (Machinet et al. 2011b).

\section{Microbial biomass}

Microbial biomass carbon (C) was quantified in soil mixed with residues (residue amended treatment) or not (control treatment) using the chloroform fumigation extraction method described by Vance et al. (1987). At dates 0, 8, 14, 21, 28, 35, 43 days of incubation, two replicates of biomass $\mathrm{C}$ by treatment were determined using $12.5 \mathrm{~g}$ equivalent dry soil. Soluble carbon in fumigated and non-fumigated soil was extracted with $50 \mathrm{ml} 0.5 \mathrm{M} \mathrm{K}_{2} \mathrm{SO}_{4}$, followed by 30 min shaking at $20^{\circ} \mathrm{C}$. The extracts were then centrifuged (15 min, 5,000 rpm) and stored at $-40{ }^{\circ} \mathrm{C}$ prior to analysis. The soluble $\mathrm{C}$ in soil extracts was determined with an auto-analyzer (BIOITECH, Analytical 1010) using an oxidation method in persulfate medium at $100{ }^{\circ} \mathrm{C}$, then measuring the resulting $\mathrm{CO}_{2}$ by infrared spectrometry. Biomass carbon was obtained from the difference in soluble carbon between fumigated and non-fumigated samples and using the biomass assimilation coefficient $\mathrm{K}_{\mathrm{EC}}=0.38$ (Vance et al. 1987).

\section{Enzyme assays}

At each date of incubation, i.e., 0, 8, 14, 21, 28, 35 and 43 days, we analyzed the activity of three enzymes involved in lignocellulose decomposition using the method reported in Grandy et al. (2007). Briefly, three replicate suspensions by treatment were prepared by homogenizing $1.0 \mathrm{~g}$ soil in $125 \mathrm{ml} 50 \mathrm{mM}$ sodium acetate buffer ( $\mathrm{pH} 5$ ) then subjected to end-over-end shaking on a rotating shaker for $1 \mathrm{~h}$ at $20^{\circ} \mathrm{C}$. The suspensions were continuously stirred on a magnetic stir plate while $0.5 \mathrm{ml}$ aliquots were pipetted in three replicates for each enzyme assay and sample. All of the enzyme assays were colorimetric.

Xylanase activity was determined on soil suspensions using RBB xylan (Remazol Brilliant Blue R $\mathrm{D}$-xylan, Fluka) as substrate. This was dissolved in hot water at $90{ }^{\circ} \mathrm{C}(1 \mathrm{~g} / 100 \mathrm{ml})$ according to Biely et al. (1988) and $0.5 \mathrm{ml}$ of this substrate solution (RBB xylan) was then added to $0.5 \mathrm{ml}$ of the suspension. These were incubated at $20{ }^{\circ} \mathrm{C}$ for $3 \mathrm{~h}$. High molecular weight fragments of the substrate (RBB xylan) were precipitated by adding $2 \mathrm{ml}$ of ethanol (96\% v/v) and shaking vigorously on a vortex shaker (Heidolph, REAX 2000), while low molecular weight fragments produced by enzyme hydrolysis remained in solution. The samples were allowed to equilibrate at $20{ }^{\circ} \mathrm{C}$ for $10 \mathrm{~min}$ before shaking and centrifuging at $5,000 \mathrm{rpm}$ for $5 \mathrm{~min}$. Absorbance of the supernatant solution was measured at $590 \mathrm{~nm}$ with a spectrophotometer (He $\lambda$ ios $\gamma$, Thermospectronic).

Cellulase was assayed by adding $2 \mathrm{~g}$ of powdered substrate (AZO-CM-Cellulose, Megazyme) to $80 \mathrm{ml}$ of boiling water on a hot plate and stirring vigorously with a magnetic stirrer until the solution was homogeneous. After cooling, $5 \mathrm{ml}$ of $2 \mathrm{M}$ sodium acetate buffer ( $\mathrm{pH} 4.5$ ) were added to the solution and both the $\mathrm{pH}$ and final volume were adjusted to 4.5 and $100 \mathrm{ml}$, respectively. A solution was prepared to precipitate high molecular fragments of the substrate (AZO-CMcellulose) by dissolving $40 \mathrm{~g}$ of sodium acetate trihydrate and $4 \mathrm{~g}$ of zinc acetate in $200 \mathrm{ml}$ of deionized water and adjusting the $\mathrm{pH}$ to 5 with $5 \mathrm{M} \mathrm{HCl}$. The final volume of this solution was increased to 11 with ethanol $(95 \%)$ and stored at room temperature. Cellulase activities were determined by following the same procedure used for xylanase activity (see above). The xylanase and cellulase activities of all soil suspension samples were determined by reference to a standard curve produced with purified endoxylanase from Thermobacillus $x y$ lanilyticus (Debeire-Gosselin et al. 1992) and commercial cellulase (322 $\mathrm{U} \mathrm{ml}^{-1}$, endo- $\beta$-glucanase purified from Aspergillus niger, Megazyme) at concentrations ranging between 0.01 and $0.1 \mathrm{U} \mathrm{ml}^{-1}$ for the cellulase and between 0.001 and $0.01 \mathrm{mU} \mathrm{ml}^{-1}$ for xylanase, both in sodium acetate buffer $(50 \mathrm{mM}$, pH 5). Laccase activity was assayed as described by Buswell et al. (1995), Floch et al. (2007). One hundred milliliters of $0.55 \mathrm{mM}$ laccase substrate (ABTS, 2,2' azinobis-3-ethylbenzothiazoline-6-sulfonic acid diammonium salt, Sigma) was prepared by using sodium acetate buffer $(50 \mathrm{mM}, \mathrm{pH} 4.5)$ followed by vigorous shaking with a magnetic stirrer. Three replicates of each soil suspension were analyzed by adding $1 \mathrm{ml}$ of suspension to $0.5 \mathrm{ml}$ of substrate 
solution (ABTS). Samples were incubated at $20{ }^{\circ} \mathrm{C}$ for $10 \mathrm{~min}$ then centrifuged at $10,000 \mathrm{rpm}$ for $5 \mathrm{~min}$ to eliminate soil particles in the reaction mixture. The absorbance of the supernatant solutions was measured at $414 \mathrm{~nm}$ with a spectrophotometer (He $\lambda$ ios $\gamma$, Thermospectronic). Laccase activity was quantified with respect to ABTS degradation by using a purified laccase from Trametes versicolor (21.8 U/mg, Sigma) at concentrations ranging from 0.001 to $0.1 \mathrm{mU} \mathrm{ml}^{-1}$ in sodium acetate buffer (50 mM, pH 4.5).

For the three enzyme assays, substrate controls wherein soil suspension was replaced by sodium acetate buffer were performed and values were deducted from assayed enzyme activities.

Data treatment and analysis

Carbon mineralization was calculated as the difference in $\mathrm{CO}_{2}$ released between the residue-amended and control soils, and rate was expressed in $\mathrm{mg} \mathrm{C} \mathrm{kg}{ }^{-1}$ soil day ${ }^{-1}$ while cumulative $\mathrm{C}$ mineralization was expressed in $\mathrm{mg} \mathrm{C} \mathrm{kg}^{-1}$ soil.

Chemical characteristics of decomposing leaves and roots were expressed in relation to the initial dry matter (non-decomposed dry matter, ND-DM) by taking into account the loss of mass by decomposition, calculated from the cumulative amounts of mineralized C (Machinet et al. 2009). These chemical analyses were performed on only two replicates at each date, as previous experiments demonstrated extremely low variation in similar results (Bertrand et al. 2006; Machinet et al. 2009, 2011a). This low number of replicates decreased the power of statistical analyses so that significant results should be viewed as conservative. In this study, we have focused our attention on glucan (both cellulose and soluble glucans) and hemicellulose (as mainly arabinoxylan), which accounted for more than $95 \%$ of the total polysaccharides measured in maize roots and leaves, as in other grass species (Brett and Waldron, 1996). Xylan mainly represents a 1-4 linked xylose backbone while arabinan represents the content of arabinose substitution of arabinoxylan and not arabinose polymers, the latter being absent from grass cell walls.

The relationships between $\mathrm{C}$ mineralization rates and main residue components were determined for days $8,14,21,28,35$ and 43 of incubation.

Enzyme activities were expressed in International Units (UI), defined as "the amount of enzyme activity which catalyzes the degradation of one micromole of the substrate per minute under standard conditions". Specific enzyme activities were calculated by dividing enzyme activities by the microbial biomass $\mathrm{C}$ and expressed as UI $\mathrm{mg}^{-1}$ biomass C. Enzyme efficiency (carbon released per unit enzyme activity) was determined from the slope of the regression of cumulative $\mathrm{C}$ mineralization ( $\mathrm{mg} \mathrm{C} \mathrm{kg}^{-1}$ soil) and cumulative enzyme activities over all sample dates (UI kg-1 soil). Cumulative enzyme activities were calculated by integrating enzyme activities over time following Sinsabaugh et al. (2002). At each date and for each treatment, enzyme activity from control soils (without maize residues) was deducted from enzyme activity measured in residue-amended soils. Relationships between cell wall chemical features and enzymes activities were determined from day 14 of incubation to avoid interferences with soluble components.

One-way anova used least significant differences (LSD) to evaluate treatment effects, and Pearson values were used to test correlations $(P \leq 0.05)$ using Statistica 10 software.

\section{Results}

\section{Carbon mineralization}

The maximum rate of carbon mineralization was greater for leaves than for roots (Fig. 2). For leaves it peaked at $40.7 \pm 1.6 \mathrm{mg} \mathrm{C} \mathrm{kg}^{-1} \mathrm{day}^{-1}$ at 8 days incubation, then decreased rapidly to $8.7 \pm 1.0 \mathrm{mg} \mathrm{C} \mathrm{kg}^{-1} \mathrm{day}^{-1}$ by day 28 , and falling more gradually to $3.7 \pm 0.4 \mathrm{mg} \mathrm{C} \mathrm{kg}^{-1} \mathrm{day}^{-1}$ by day 43 (Fig. 2). The $\mathrm{C}$ mineralization pattern was different for roots, showing little variation between day 8 and 21 (mean $=19.5 \pm 0.3 \mathrm{mg} \mathrm{C} \mathrm{kg}^{-1} \mathrm{day}^{-1}$ ), then decreasing to $7.3 \pm 0.6 \mathrm{mg} \mathrm{C} \mathrm{kg}^{-1}$ day $^{-1}$ at day 43 , which was significantly $(P \leq 0.001)$ higher than for leaves on this date. The cumulative amount of carbon mineralized was significantly higher for leaves $(39.1 \% \pm 1.4$ of added C) than roots $(32.1 \% \pm 0.7)$ by the end of incubation (data not shown).

Chemical characteristics of leaves and roots

The initial carbon and nitrogen content of maize leaves and roots were $46-47$ and $1.1-1.9 \%$ of the total 


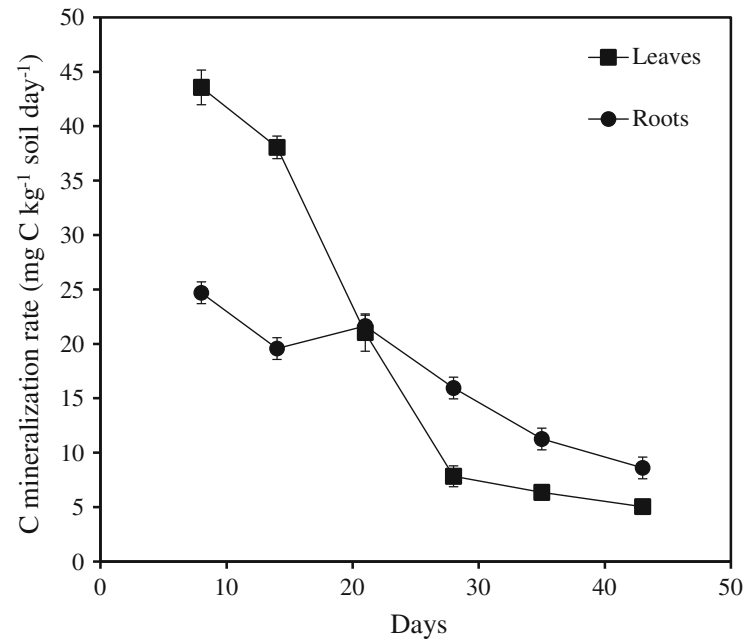

Fig. 2 Carbon mineralization rate measured in soil after addition of maize leaves and roots. Values from control soil (i.e. soil without residue added) were subtracted. Data are means of 4 incubation replicates $(n=4)$

dry matter, respectively (Table 1), leading to C:N ratios of 24 for leaves and 43 for roots. Roots had higher cell wall content than leaves, and thus less soluble content. Polysaccharides were the major constituents of maize residues and glucan, mostly derived from cellulose, was the main sugar. Glucan represented nearly $10 \%$ more of the dry matter (DM) in roots than in leaves whereas the content of xylan (X), which was the second most abundant sugar, was identical for both residues. Hemicellulose (arabinoxylan) content was calculated as the sum of xylan and arabinan (A) leading to slightly higher content in leaves than in roots due to higher arabinan concentration in leaves. The substitution level of arabinoxylan chains was estimated by the arabinan to xylan ratio $(\mathrm{A} / \mathrm{X})$, which was higher in leaves than in roots (Table 1). The amount of KL-lignin accounted for $13-18 \%$ of residue dry matter and was higher in roots than in leaves. Total phenolic acids were nearly seven times more abundant in roots than in leaves (Table 1). $p$-Coumaric (PCA) acids were more abundant than FA, leading to PCA:FA ratios above 1 , and greater in maize roots than leaves.

During decomposition, the amounts of glucan, xylan and arabinan were assessed after 8, 14, 21, 28, 35,43 days of decomposition for maize leaves and roots and reported in Fig. 3 as $\mathrm{mg} \mathrm{g}^{-1}$ of original dry
Table 1 Chemical characteristics of maize leaves and roots before decomposition

\begin{tabular}{lll}
\hline & Leaves & Roots \\
\hline$\%$ dry matter & & \\
Total-C & $45.62 \pm 0.01$ & $47.30 \pm 0.08$ \\
Total-N & $1.92 \pm 0.01$ & $1.11 \pm 0.01$ \\
C-to-N ratio & 24 & 43 \\
Soluble fraction & $26.57 \pm 0.08$ & $15.89 \pm 0.40$ \\
Polysaccharides, \% dry matter & \\
Glucan & $36.95 \pm 1.19$ & $47.14 \pm 3.05$ \\
Xylan (X) & $25.79 \pm 0.80$ & $26.14 \pm 1.8$ \\
Arabinan (A) & $4.37 \pm 0.17$ & $1.50 \pm 0.01$ \\
Hemicellulose & $30.28 \pm 0.80$ & $27.64 \pm 1.82$ \\
A/X & $0.17 \pm 0.01$ & $0.06 \pm 0.01$ \\
Phenols, \% dry matter & & \\
KL-Lignin & $12.84 \pm 0.43$ & $17.52 \pm 0.31$ \\
Phenolic acids & $0.56 \pm 0.04$ & $3.88 \pm 0.16$ \\
PCA/FA & $1.20 \pm 0.02$ & $3.31 \pm 0.04$ \\
\hline
\end{tabular}

Data represent the mean of two replicates

matter. In leaves, glucan contents decreased rapidly from days 0 to 21 with more than $90 \%$ of the initial glucan decomposed during this period (Fig. 3a). From days 20 to the end of incubation, the mean value of remaining glucans represented about $12 \%$ of the initial content. The decomposition of xylans followed the same pattern but was less drastic with $61 \%$ of xylans lost during the first 14 days of incubation and reaching about $80 \%$ loss at 43 days (Fig. 3a). The decrease in arabinan content occurred mainly during the first 2 weeks of decomposition and represented $70 \%$ of the initial content of leaves at day 43 (Fig. 3a).

The dynamics of these components were different in decomposing roots. Glucan and xylan contents in roots decreased mostly during the first 8 days of decomposition, remained constant between days 8 and 14, decreased again between days 14 and 21, and remained constant between days 21 to 43 (Fig. 3b). The extent to which glucan and xylan were degraded by 43 days represented 63 and $57 \%$ of their initial contents, respectively, which was lower than loss during leaf degradation. Arabinan content of roots slightly increased during the first 8 days of decomposition and then remained constant to the end of the incubation period (Fig. 3b). 

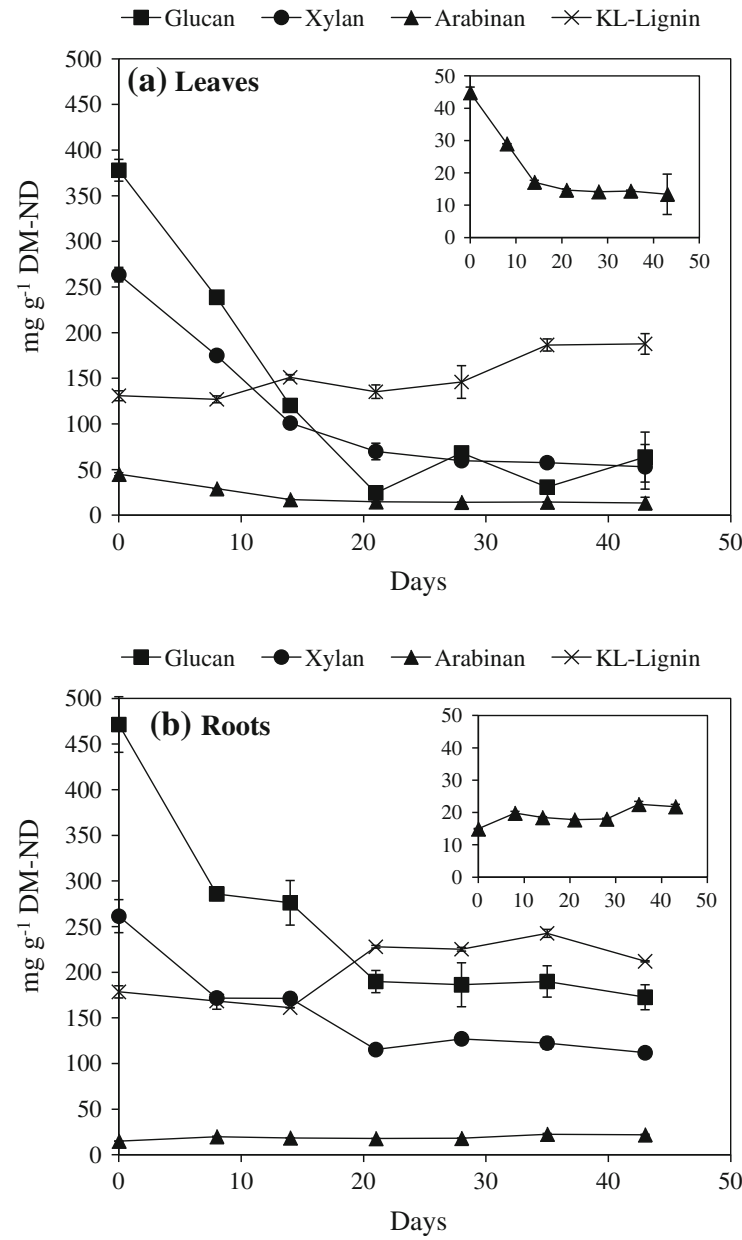

Fig. 3 Decomposition of glucan, xylan, arabinan and Klason lignin from maize leaves (a) and roots (b) in a soil. Values were corrected for dry matter loss during decomposition and are expressed as $\mathrm{mg} \mathrm{g}^{-1}$ dry Matter of non-decomposed residues (DM-ND). Data are means of 2 replicates $(n=2)$

For both root and leaf residues, changes in xylan and glucan contents showed positive significant relationships during decomposition $\left(\mathrm{R}^{2}=0.94\right.$ and 0.90 for roots and leaves respectively) (data not shown). Arabinan and xylan content of decomposing leaves were positively $(P<0.001)$ and significantly correlated $\left(\mathrm{R}^{2}=0.94\right)$ whereas arabinan content was not significantly related to xylan content in roots $\left(\mathrm{R}^{2}=0.05\right)$ (data not shown).

KL-Lignin remained constant in roots to day 14 of decomposition then slightly increased between days 21 and 43, with a mean value of $22.7 \pm 1.2 \% \mathrm{DM}$ over this period (Fig. 3b). A progressive increase in KL-Lignin to a peak of $18.8 \pm 1.1 \%$ at day 43 was also recorded during leaf decomposition (Fig. 3a).
Relationships between residue chemical characteristics and $\mathrm{C}$ mineralization

Relationships between chemical features of decomposing maize leaves and roots (i.e., glucan, $\mathrm{X}, \mathrm{A}$, KL-Lignin/glucan, A/X, KL-Lignin/(A+X)) and $\mathrm{C}$ mineralization rates were determined from day 8 to 43 (Table 2). The degradation of glucan, xylan and arabinan was positively and significantly $(P \leq 0.01$; $P \leq 0.001$ and $P \leq 0.001)$ related to $\mathrm{C}$ mineralization rates in leaves. In contrast, $\mathrm{C}$ mineralization rates in roots exhibited a positive relationship $(P \leq 0.05)$ to only glucan degradation, no correlation to xylan and a significant $(P \leq 0.05)$ negative relationship to arabinan. For leaves, KL-Lignin and KL-Lignin/ $(\mathrm{A}+\mathrm{X})$ were negatively correlated to $\mathrm{C}$ mineralization rate $(P \leq 0.01)$. However, the ratio of KL-Lignin/glucan was negatively related to $\mathrm{C}$ mineralization rate for both leaves and roots $(P \leq 0.05)$. A/X was significantly and negatively correlated with $\mathrm{C}$ mineralization rate in leaves $\left(\mathrm{R}^{2}=0.92 ; P \leq 0.001\right)$ and to a lesser extent $\left(\mathrm{R}^{2}=0.62 ; P \leq 0.01\right)$ in roots (Fig. 4$)$.

Changes in microbial biomass $\mathrm{C}$ and enzyme activities and relationships to residue chemical characteristics

No significant variations in microbial biomass $C$ were observed in the control soil (without residue) over time (Table 3). In contrast, biomass $\mathrm{C}$ increased significantly in both the leaf- and root-amended soils (Table 3), although soils incubated with leaves and roots did not follow the same pattern. In leaf-amended soils, a rapid increase in microbial biomass $\mathrm{C}$ occurred from day 8 to 14 , followed by a slight decline by the end of incubation. Peak values were about $34 \%$ higher than initial biomass. In contrast, no increase in biomass $\mathrm{C}$ was recorded in root-amended soils until day 21 , whereupon the biomass reached significantly higher, relatively constant values to the end of incubation. Peak values were about $17 \%$ higher than initial levels.

Enzyme activities in the control soil did not vary significantly $(P \leq 0.05)$ over time (see supplementary data). However, the addition of maize residues significantly increased enzyme activities even at day 0, i.e., $10 \mathrm{~min}$ after residue addition. Enzyme activity was higher in leaf-amended soils than in root-amended soils, for example, cellulase activity in leaf-amended 
Table 2 Regression coefficients $\left(\mathrm{R}^{2}\right)$, slope and intercept of the rate of $\mathrm{C}$ mineralized $\left(\mathrm{mg} \mathrm{C}-\mathrm{CO}_{2} \mathrm{~kg}^{-1}\right.$ soil day ${ }^{-1}$ ) with the evolution of the main residue components $\left(\mathrm{mg} \mathrm{g}^{-1} \mathrm{DM}-\mathrm{ND}\right)$ during soil decomposition $(n=6$ dates $\times 2$ replicates)

\begin{tabular}{|c|c|c|c|c|c|c|c|c|}
\hline & & \multicolumn{7}{|c|}{ Rate of $\mathrm{C}$ mineralized with } \\
\hline & & Glucan & Xylan (X) & Arabinan (A) & KL-Lignin & $\begin{array}{l}\text { KL-Lignin } \\
\text { /Glucans }\end{array}$ & $\mathrm{A} / \mathrm{X}$ & KL-Lignin/(A+X) \\
\hline \multirow{3}{*}{$\begin{array}{l}\text { Leaves } \\
\qquad(n=12)\end{array}$} & $\mathrm{R}^{2}$ & $0.62 * *$ & $0.76 * * *$ & $0.67 * * *$ & $0.52 * *$ & $0.39 *$ & $0.92 * * *$ & $0.65 * *$ \\
\hline & Slope & 0.16 & 0.29 & 2.04 & -4.23 & -42.29 & -425.84 & -119.48 \\
\hline & Intercept & 4.90 & -5.96 & -16.71 & 84.83 & 32.26 & 111.66 & 41.42 \\
\hline \multirow{3}{*}{$\begin{array}{l}\text { Roots } \\
(n=12)\end{array}$} & $\mathrm{R}^{2}$ & $0.38 *$ & $0.32^{\mathrm{ns}}$ & $0.48 * *$ & $0.21^{\mathrm{ns}}$ & $0.34 *$ & $0.62 * *$ & $0.24^{\mathrm{ns}}$ \\
\hline & Slope & 0.07 & 0.12 & -1.95 & -0.79 & -98.90 & -128.69 & -70.60 \\
\hline & Intercept & -0.07 & -1.26 & 53.19 & 31.05 & 24.82 & 34.03 & 24.46 \\
\hline
\end{tabular}

Asterisk represent the following level of significance: $* P \leq 0.05 ; * * P \leq 0.01 ; * * * P \leq 0.001$; ns $=$ no significant

soils was 2-3 times higher. Activities of xylanase and laccase followed almost exactly the same patterns with overall activity levels: cellulase $>$ xylanase $>$ laccase (see supplementary data).

Specific enzyme activities (per unit microbial biomass) were then compared to the amounts of their corresponding substrates (Fig. 5). Specific enzyme activities measured in leaf-amended treatments tended to increase with the amount of glucan or xylan (Fig. 5a, b). In roots, cellulase specific activities were positively $(P \leq 0.01)$ related to residue glucan concentration whereas xylanase specific activities were not related to xylan. Specific activities of laccase were negatively correlated $\left(\mathrm{R}^{2}=0.62 ; P \leq 0.01\right)$ with KLLignin in root-amended soils but this relationship was not significant in the leaf treatment (Fig. 5c). In both leaves and roots, cellulase and xylanase specific activities were mostly related to the substitution level of arabinoxylan chains (A/X) and the KL-Lignin/ $(\mathrm{A}+\mathrm{X})$ ratio. In contrast, laccase specific activities were related to all three indices in roots, but no index of residue quality in leaves (see supplementary data).

The plots of cumulative respiration versus cumulative enzymes activities are represented in Fig. 6 for the three enzymes studied. As expected, all relationships were positive and highly significant $(P<0.001)$. Enzyme efficiencies calculated from the slope of these relationships were systematically lower for leaves than for roots and varied with enzyme type (Fig. 6). Cellulases were the most abundant enzymes but presented the lowest efficiency while laccase was present in the lowest amounts and exhibited the highest efficiency, in terms of respiratory activity.

\section{Discussion}

Dynamics of residue chemical features during decomposition

Maize leaves were enriched in soluble components compared to roots, which explains their higher initial $\mathrm{C}$ mineralization rate (Fig. 2) and the very sharp decrease in glucan content (Fig. 3a). Indeed, glucans and arabinoxylans are present in polymer form, i.e., cellulose and hemicelluloses, respectively, thus constituting the primary structural carbohydrates of plant cell walls (Brett and Waldron 1996). However a portion of these sugars is also present in the soluble fraction of residue (starch, amino sugars) and is easily degradable (Gunnarsson et al. 2008; Bertrand et al. 2009). The rapid lost of glucans and xylans observed during the first 8 and 14 days for roots and leaves, respectively, could thus be explained by the degradation of these soluble sugars (Bertrand et al. 2009) which were more abundant in leaves than in roots. After this period, cell wall polymers, which are more recalcitrant, are likely to decompose. Therefore the observed temporal pattern of $\mathrm{C}$ mineralization rate is in agreement with the conceptual model of Berg and Matzner (1997), with a rapid initial decline in soluble substrates followed by the decomposition of more complex cell wall polymers.

Maize leaves and roots offer two very different type of cell wall quality with regards to the level of phenol components (lignin, phenolic acid) and the arabinose substitution of arabinoxylans which are the major hemicelluloses interacting with both lignin and 


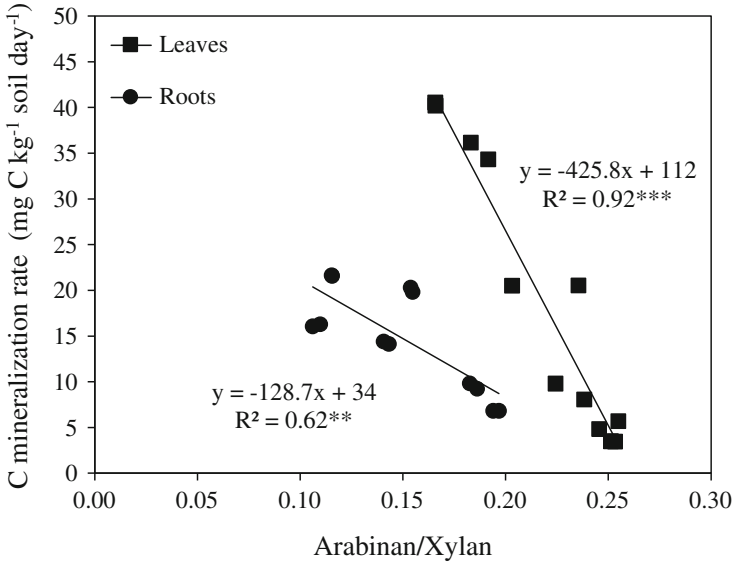

Fig. 4 Relationships between the rate of $\mathrm{C}$ mineralized expressed as $\mathrm{mg} \mathrm{C} \mathrm{kg}^{-1}$ soil day ${ }^{-1}$ and the ratio arabinan to xylan which reflects polysaccharides level of ramification. Data represents two replicates at each sampling date i.e. days 8,14 , $21,28,35$ and 43

cellulose in grass (Fig. 1; Table 1). Leaves mainly consist of thin-walled mesophyllic cells with a low proportion of fibers and vessels rich in lignified secondary walls while roots mostly consist of thickwall highly lignified fibers and parenchyma (Esau 1977). Leaves and roots could thus be considered as residues rich in primary and secondary cell walls, respectively (Hatfield and Chaptman 2009; Jung and Phillips 2010) (Fig. 1). The strong positive relationships between the rate of $\mathrm{C}$ mineralized from day 14 to 43 and polysaccharide content in leaves (Table 2) indicate that polysaccharides in the low-lignified primary cell wall are easily decomposed. In this respect, the rapid and concomitant decrease in arabinan and xylan in decomposing leaves indicates that most of the arabinose substitutions did not hamper xylan degradation in low-lignified cell walls (Figs. 1, 4). However, at the end of the 43 days incubation only lignified cell walls were remaining in the decomposing leaves. The slower decomposition of roots is in agreement with the greater recalcitrance of polysaccharides in lignified cell walls. Not only more lignin but also the more complex cell wall network decreased degradability (i.e., higher phenolic acid contents; Table 1; Fig. 1). The difference in slopes obtained when $\mathrm{C}$ mineralization rate was related to $\mathrm{A} / \mathrm{X}$ ratio during decomposition demonstrates that root xylan was less degradable than leaf xylan (Fig. 4). Moreover, the lack of a significant relationship between arabinan and xylan during root decomposition (data not shown) suggests that arabinose substitutions are involved in cross-linkage between hemicelluloses and lignin in root, which impairs the degradation of polysaccharide (Fig. 1).

Therefore, we demonstrate that the level of substitution of arabinoxylans in grasses provides a good explanation of the controls on decomposition process. Moreover, a distinction should be made between cell wall type, i.e., primary or secondary cell walls, which regulate enzyme efficiencies differently. For plant parts enriched in primary cell walls (leaves), the level of arabinose substitution controls $\mathrm{C}$ mineralization rate and hampers polysaccharide decomposition to a lesser extent than in plant parts containing mostly lignified secondary cell walls (stem and roots). In the latter, arabinose substitutions are mostly cross-linked with lignin thus decreasing enzyme accessibility (Fig. 1).

Enzyme activity and efficiency as influenced by litter chemistry

An interesting feature of our study is that enzyme specific activity was always higher in leaf than root amended soils. Considering cell wall polymer hydrolysis (i.e., after 14 days incubation), cellulases show high, positive and significant relationships with the

Table 3 Microbial biomass $\mathrm{C}$ at different stages of incubation measured in soils with maize residues and without (control)

\begin{tabular}{|c|c|c|c|c|c|c|c|c|}
\hline Incubation time (days) & 0 & 8 & 14 & 21 & 28 & 35 & 43 & LSD \\
\hline \multicolumn{9}{|c|}{$\mathrm{mg}$ biomass $\mathrm{C} \mathrm{kg}^{-1}$ dry soil } \\
\hline Control soil & $161 \mathrm{a}$ & nd & nd & $180 \mathrm{a}$ & nd & nd & $178 \mathrm{a}$ & 19.9 \\
\hline Soil + maize leave & $273 a$ & $346 \mathrm{~cd}$ & $366 \mathrm{~d}$ & $337 \mathrm{bcd}$ & $311 b$ & $313 \mathrm{bc}$ & $315 b c$ & 37.1 \\
\hline Soil + maize root & $275 a$ & $275 a$ & $291 \mathrm{ab}$ & $320 \mathrm{~b}$ & $322 b$ & $291 \mathrm{ab}$ & $323 b$ & 37.2 \\
\hline
\end{tabular}

Data are means of two measurements. Means not sharing a common letter within a row are significantly different $(P \leq 0.05)$

$L S D$ states for least significant differences, $n d$ for not determined 

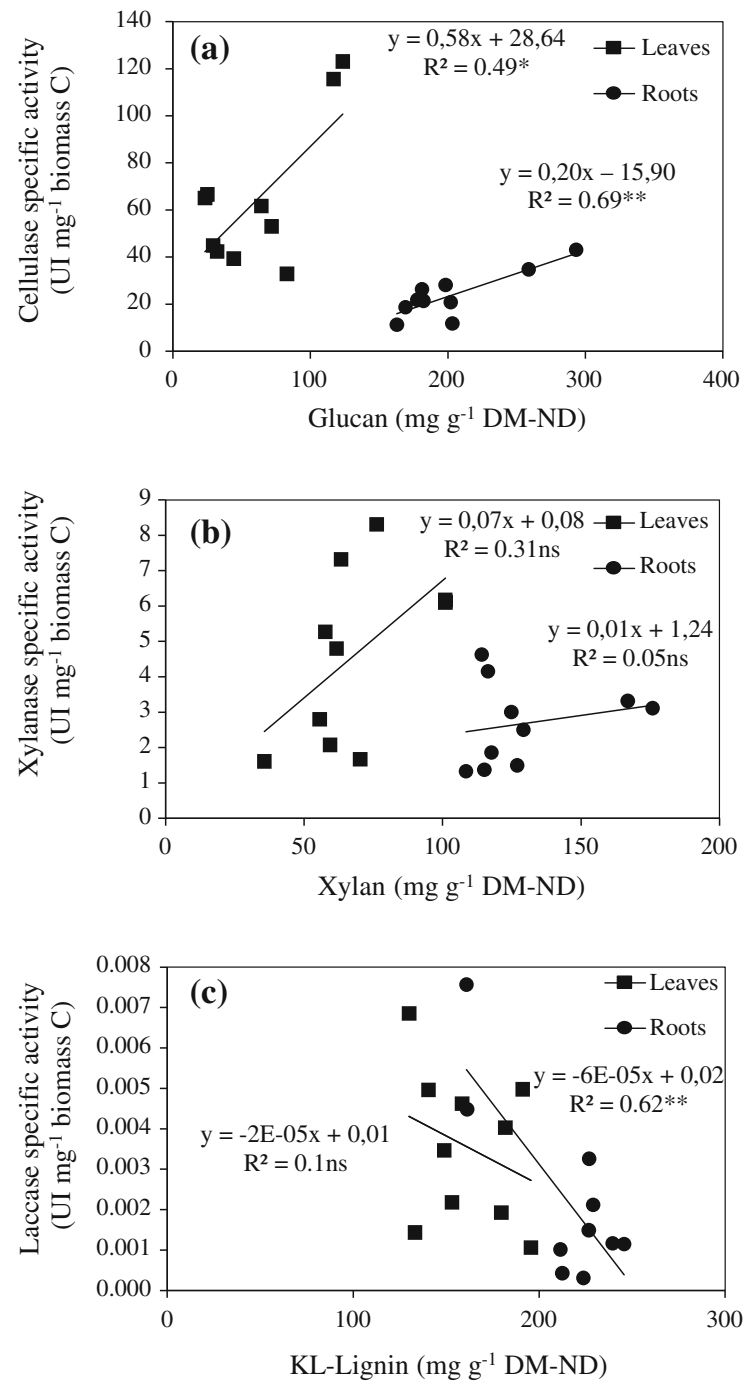

Fig. 5 Relationships between enzyme specific activities expressed as $\mathrm{UI} \mathrm{mg}^{-1}$ biomass $\mathrm{C}$ and their corresponding substrates expressed as $\mathrm{mg} \mathrm{g}^{-1}$ DM-ND during cell wall decomposition (i.e. days 14, 21, 28, 35 and 43 of incubation). Relationships are represented for cellulase (a), xylanase (b) and laccase (c)

levels of glucan, suggesting that soil microorganisms use glucan (cellulose) as the preferred substrate irrespective of the type of residue (Leitner et al. 2012) (Fig. 5a), and that enzyme production was responsive to substrate availability (Leinweber et al. 2008). However, for both residues (leaves and roots) the relationships between glucan and cellulase were mainly driven by measurements performed at day 14 (highest values), meaning that cellulase specific activity decreased with decomposition as cell wall
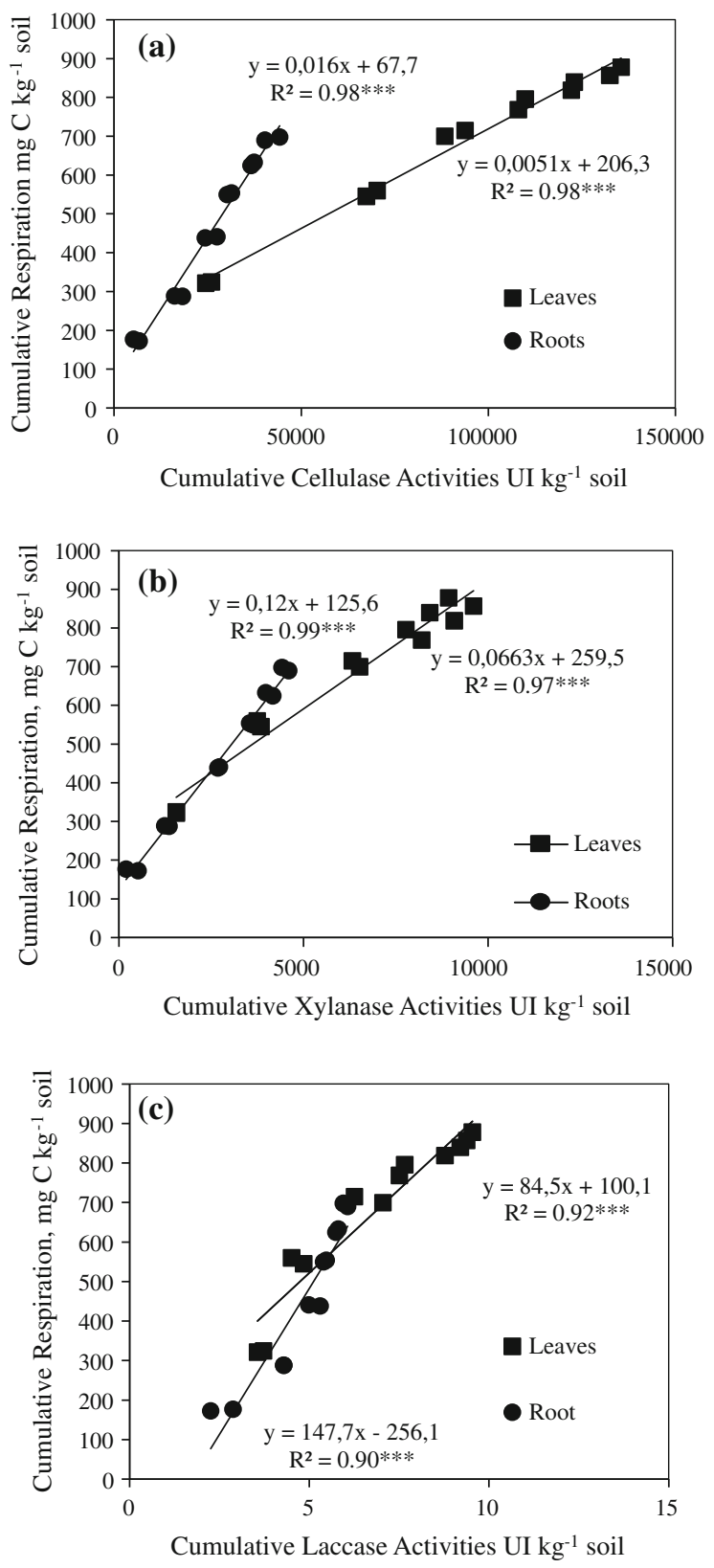

Fig. 6 Relationships between cumulative respiration (mg C kg-1 soil) and cumulative enzyme activities (UI kg-1 soil) during soil decomposition for cellulase (a), xylanase (b) and laccase (c). Two replicates are represented at each date (i.e. days 8, 14, 21, 28, 35 and 43). Enzyme efficiencies are defined by the slope of these relationships

complexity increased. This pattern also suggests that cellulases were negatively impacted not only by lignin content (KL-lignin) but also by cell wall chemical features such as KL-lignin/(A+X); KL-lignin/Glucan; $\mathrm{A} / \mathrm{X}$, particularly for roots (see supplementary data). 
Xylanases were not significantly related to xylan concentration and also exhibited differences between leaves and roots in efficiency with regards to xylan content (Fig. 5b) and carbon mineralization (Fig. 6b). However, the decreasing xylanase activity with increasing $\mathrm{A} / \mathrm{X}$ ratio in decomposing leaves and, to a lesser extent, roots suggests that the cross-linked arabinoxylan network inhibits microbial xylanases, as previously shown for pure xylanase acting on weakly lignified wheat bran tissues (Beaugrand et al. 2004). Indeed, the catalytic action of some xylanases can be prevented by the proximity of $\mathrm{A} / \mathrm{X}$ substitution and require accessory enzymes working in concert with xylanases. For this reason, differences in xylanase efficiency between leaves and roots may result from both the specific catalytic activity of extracellular endoxylanases that cleave the xylan backbone, as well as the activity of accessory enzymes.

Similar limitations may also restrict cellulose accessibility to cellulases as shown by the negative relationships between cellulase activities and $\mathrm{A} / \mathrm{X}$ ratio (see supplementary data). This result is consistent with the synergistic action of xylanase and cellulase acting on lignocelluloses as demonstrated in biorefinery applications (Hu et al. 2011). Clearly, it is not merely the sizes of the substrate pools that define enzyme activity and efficiency, but also the biochemical relationships among these distinct pools. To our knowledge, this study is the first to assess enzyme efficiency, i.e., the amount of enzyme activity required to decompose the litter, in experiments performed under such tightly controlled conditions. Indeed Sinsabaugh et al. (2002) and recently Wickings et al. (2012) determined enzyme efficiency in decomposing litter bags under field conditions and noted the importance of other environmental variables, such as climate and soil type, on their results.

Our findings suggest that in the presence of a high quality substrate (maize leaves), microorganisms exhibit initial, rapid growth and produce enzymes that are not very efficient in degrading recalcitrant substrates such as cell walls. However, these enzymes might produce an apparent priming effect (Kuzyakov 2010) driven by the high soluble content of leaves. Inversely, the slower decomposition of roots had a higher efficiency of enzyme activity perhaps as a result of a slower growing microbial biomass. K-selected microorganisms would be expected to degrade more recalcitrant resources slowly but more efficiently whereas r-selected microorganisms should grow more rapidly on easily available substrates (Pianka 1970). Perhaps a relatively larger proportion of K- versus r-selected microorganisms on decaying roots produced less enzyme, but with a higher efficiency to degrade recalcitrant organic matter (Blagodatskaya et al. 2007). This suggests that the litter quality could provide a shift in function of the microbial community through enzyme production as suggested by Berg and McClaugherty (2008).

Our data illustrate the key role of fine litter chemistry in regulating enzyme activity and respiration by microorganisms over a short incubation period. For example, we found that laccase activities decreased with root decomposition as lignin content increased, along with other lignin-related cell wall complexities, but there was no significant relationship for leaves (Fig. 5c). Interestingly, laccase was the only enzyme present at the same level in leaves and roots at the beginning of the incubation (up to day 14), and respiration was consistently related to laccase in both leaves and roots (Fig. 6c). Fewer polysaccharides remained in leaves than roots after day 14 of incubations per amount of remaining lignin and level of arabinose substitution (Figs. 2, 3). Because the amount of lignin-embedded polysaccharides was relatively higher in roots, when laccase oxidized and decreased the hydrophobicity of lignin, thereby preventing nonspecific binding of glycoside hydrolases, it also increased the cost-effectiveness of the synergistic action of hydrolytic and oxidative enzymes (Fig. 6a, c), as previously shown for paper pulp or wood decay (Blanchette et al. 2007; Palonen et al. 2004). This synergy in enzymes action could explain the systematically higher efficiency of enzymes associated with the more recalcitrant roots as compared to the more easily decomposed leaves.

Implications to enzyme-based modeling

Mathematical models of litter decay have recently begun to include the production, activity and turnover of extracellular enzymes (e.g., Allison et al. 2010; Folse and Allison 2012; Moorhead et al. 2012; Resat et al. 2012). Because most enzymes attack specific substrates, substrate chemistry is an important controller. For example, the inhibitory effects of lignin on hydrolytic enzyme activities are well known (e.g., Blanchette et al. 2007; Palonen et al. 2004) and its effects on litter decay have been modeled for decades (e.g., Meentemeyer 
1978). However, we are unaware of any models that consider the effects of the basic, structural crosslinkages between arabanoxylans and lignins on access to the more readily degradable polysaccharides. In fact, few enzyme-based models include more than a single type of enzyme (e.g., Allison 2005; Folse and Allison 2012; Moorhead et al. 2012). As models become more realistic in terms of enzyme kinetics they also need to become more realistic in terms of the biochemical relationships between the substrates they degrade.

One of the critical uncertainties in enzyme-based decomposition models is how much gain in resource is accrued per microbial investment in enzymes. In other words, what is the efficiency of enzyme activity? For example, existing models typically assume a fractional allocation of microbial resources to enzyme production, which then hydrolyze insoluble polysaccharides to soluble sugars for microbial uptake. This resource is allocated to enzyme production, microbial growth and respiration for maintenance, growth and overflow metabolism (e.g., Schimel and Weintraub 2003, Allison 2005, Moorhead et al. 2012). These models include many assumptions about the efficiencies of C-transformations, which together estimate an overall, enzyme efficiency. To our knowledge, the present study is the first to provide an integrated assessment of specific enzyme activities with degradation of corresponding cell wall compounds (Fig. 5), and measure of microbial resource use (i.e., respiration; Fig. 6). As such, it quantifies enzyme efficiency with respect to two metrics, specific substrate degradation and microbial metabolism, which can be used to test model assumptions and behavior. Indeed, the slopes of the equations shown in Fig. 6 quantify the net yield in microbial respiratory activity per unit of enzyme activity and thus provide constraints on these relationships for models.

\section{Conclusions}

Our work demonstrates that litter initial quality is driving enzyme efficiency by modulating accessibility of cell wall polysaccharides, which is one of the main rate-limiting steps of decomposition. This implies that the polysaccharide level of ramification (i.e., A/X ratio) provides a relevant indication of the negative impact of the cell wall network upon cellulase and xylanase efficiency in grass residues. Given the predominant role of ferulic cross linkage in the xylan chain and between xylan and lignin, determination of debranching enzymes such as feruloyl esterase or arabinofuranosidase may provide new information at early steps of plant residue decomposition. This information, in turn would provide deeper insight to the controls on enzyme efficiency, such as its relationship to carbon mineralization in soil.

This study also demonstrates that litter quality is regulating decomposer strategy. While $\mathrm{K}$ strategist microorganisms were often reported to colonize low litter quality our results suggest that a slower growing pool of microorganisms produced more efficient enzymes than a faster growing pool of $r$ strategist microorganisms developing on high quality litter. Moreover, we propose that this difference in enzyme efficiencies is due to the synergistic actions of hydrolytic and oxidative enzymes, which is more important in substrates having a high proportion of lignin embedded polysaccharides. However molecular determination of the evolution of soil microorganisms (fungi and bacteria) during decomposition would be necessary to confirm this point.

Finally, the results of the present study underscore the importance of concurrently monitoring biomass size and activity, enzyme activity, and substrate chemistry. Without concurrent measurements, the variations among relationships within this biomassenzyme-substrate system would not have been observed. It also further emphasized the importance of explicitly linking enzyme efficiency to litter chemical architecture and resulting patterns of organic matter degradation for mathematical models.

Acknowledgments This study was financially supported by the National Institute of Agronomic Research (INRA) Reims, France, the Higher Education Commission (HEC) of Pakistan, and NSF Ecosystem Sciences program (DEB-0918718). The skillful technical assistance of Gonzague ALAVOINE, Sylvie MILLON, Olivier DELFOSSE and David CRÔNIER is gratefully acknowledged.

Open Access This article is distributed under the terms of the Creative Commons Attribution License which permits any use, distribution, and reproduction in any medium, provided the original author(s) and the source are credited.

\section{References}

Allison SD (2005) Cheaters, diffusion and nutrients constrain decomposition by microbial enzymes in spatially structured environments. Ecol Lett 8:626-635 
Allison SD, Vitousek PM (2004) Extracellular enzyme activities and carbon chemistry as drivers of tropical plant litter decomposition. Biotropica 36:285-296

Allison SD, Wallenstein MD, Bradford MA (2010) Soil carbon response to warming dependent on microbial physiology. Nat Geosci 3:336-340

Beaugrand J, Crônier D, Thiebeau P, Schreiber L, Debeire P, Chabbert B (2004) Structure, chemical composition, and xylanase degradation of external layers isolated from developing wheat grain. J Agric Food Chem 52:7108-7117

Berg B, Matzner E (1997) Effect of N deposition on decomposition of plant litter and soil organic matter in forest systems. Environ Rev 5:1-25

Berg B, McClaugherty C (2008) Plant litter: decomposition, humus formation, carbon sequestration, 2nd edn. Springer, New York

Berlin A, Balakshin M, Gilkes, Kadla J, Maximenko V, Kubo S, Saddler J (2006) Inhibition of cellulase, xylanase and betaglucosidase activities by softwood lignin preparations. J Biotechnol 125:198-209

Bertrand I, Chabbert B, Kurek B (2006) Can the biochemical features and histology of wheat residues explain their decomposition in soil? Plant Soil 281:291-307

Bertrand I, Prevot M, Chabbert B (2009) Soil decomposition of wheat internodes of different maturity stages: relative impact of the soluble and structural fractions. Bioresour Technol 100:155-163

Biely P, Mislovicova D, Toman R (1988) Remazol brilliant blue xylan: a soluble chromogenic substrate for xylanases. Methods Enzymol 160:536-541

Blagodatskaya EV, Blagodatsky SA, Anderson TH, Kuzyakov Y (2007) Priming effects in Chernozem induced by glucose and $\mathrm{N}$ in relation to microbial growth strategies. Appl Soil Ecol 37:95-105

Blanchette R, Krueger E, Haight J, Akhtar M, Akin D (1997) Cell wall alterations in loblolly pine wood decayed by the white-rot fungus, Ceriporiopsis subvermispora. J Biotechnol 53:203-213

Brett CT, Waldron KW (1996) The molecular components of the wall. In: Black M, Charlwood B (eds) Physiology and biochemistry of plant cell walls. Chapman and Hall, London, pp 4-43

Buswell JA, Cai YJ, Chang ST (1995) Effect of nutrient nitrogen and manganese on manganese peroxidase and lactase production by Lentinula (Lentinus) edodes. FEMS Microbiol Lett 128:81-88

Chesson A (1988) Lignin-polysaccharide complexes of the plant cell wall and their effect on microbial degradation in the rumen. Anim Feed Sci Technol 21:219-228

Chesson A (1997) Plant degradation by ruminants: parallels with litter decomposition in soils. In: Cadish G, Giller KE (eds) Driven by nature. Plant litter quality and decomposition. CAB International, Wallingford, pp 47-66

Debeire-Gosselin M, Loonis M, Samain E (1992) Purification and properties of $22 \mathrm{kDa}$ endoxylanase excreted by a new strain of thermophilic Bacillus. In: Visse J, Beldman G, Kusters-van, Somern MA, Voragen AGJ (eds) Xylan and xylanases. Elsevier, Amsterdam, pp 463-466

Esau K (1977) Anatomy of seed plants. Wiley, New York
Floch C, Alarcon-Gutierrez E, Criquet S (2007) ABTS assay of phenol oxidase activity in soil. J Microbiol Methods 71:319-324

Folse HJ, Allison SD (2012) Cooperation, competition, and coalitions in enzyme-producing microbes: social evolution and nutrient depolymerization rates. Front Microbiol $3: 1-10$

Goering HK, van Soest PG (1970) Forage fiber analysis (apparatus, reagents, procedures and some applications) USDA Agricultural Handbook No. 379. Agricultural Research Service, USDA, Washington, DC

Grandy AS, Neff JC, Weintraub MN (2007) Carbon structure and enzyme activities in alpine and forest ecosystems. Soil Biol Biochem 39:2701-2711

Gunnarsson S, Marstorp H, Dahlin AS, Witter E (2008) Influence of non-cellulose structural carbohydrate composition on plant material decomposition in soil. Biol Fertil Soils 45:27-36

Hatfield RD, Chaptman AK (2009) Comparing-corn types for differences in cell wall characteristics and $p$-Coumaroylation of Lignin. J Agric Food Chem 57:4243-4249

Heal OW, Anderson JM, Swift MJ (1997) Plant litter quality and decomposition: an historical overview. In: Cadish G, Giller KE (eds) Driven by nature: plant litter quality and decomposition. CAB International, Wallingford, pp 3-30

Himmel ME (2007) Biomass recalcitrance: engineering plants and enzymes for biofuels production. Science 315:804-807

Hu J, Arantes V, Saddler JN (2011) The enhancement of enzymatic hydrolysis of lignocellulosic substrates by the addition of accessory enzymes such as xylanase: is it an additive or synergistic effect? Biotechnol Biofuels 4:36

Huyen TLN, Rémond C, Dheilly RM, Chabbert B (2010) Effect of harvesting date on the composition and saccharification of Miscanthus $\times$ giganteus. Bioresource Technol 110:8224-8231

Iiyama K, Lam TBT, Stone BA (1990) Phenolic acids bridges between polysaccharides and lignin in wheat internodes. Phytochem 29:733-737

Jung HG, Phillips RL (2010) Putative seedling ferulate ester (sfe) maize mutant: morphology, biomass yield, and stover cell wall composition and rumen degradability. Crop Sci 50:403-418

Kuzyakov Y (2010) Priming effects: interactions between living and dead organic matter. Soil Biol Biochem 42:1363-1371

Lam TBT, Iiyama K, Stone BA (2003) Hot alkali-labile linkages in the walls of the forage grass Phalaris aquatica and Lolium perenne and their relation to in vitro wall digestibility. Phytochemistry 64:603-607

Leinweber P, Jandl G, Baum C, Eckhardt KU, Kandeler E (2008) Stability and composition of soil organic matter control respiration and soil enzyme activities. Soil Biol Biochem 40:1496-1505

Leitner S, Wanek W, Wild B, Haemmerle I, Khol L, Keiblinger KM, Zechmeister-Boltenstern S, Richter A (2012) Influence of litter chemistry and stoichiometry on glucan depolymerization during decomposition of beech (Fagus sylvatica L.) litter. Soil Biol Biochem 50:174-187

Machinet GE, Bertrand I, Chabbert B, Recous S (2009) Decomposition in soil and chemical changes of maize roots with genetic variations affecting cell wall quality. Eur $\mathbf{J}$ Soil Sci 60:176-185 
Machinet GE, Bertrand I, Barriere Y, Chabbert B, Recous S (2011a) Carbon mineralization of sixteen maize root genotypes: impact of cell wall characteristics to explain their decomposition in soil on a long term incubation experiment. Soil Biol Biochem 43:1544-1552

Machinet GE, Bertrand I, Chabbert B (2011b) Assessment of Lignin-related compounds in soils and maize roots by alkaline oxidations and thioacidolysis. Soil Sci Soc Am J 75:542-552

Meentemeyer V (1978) Macroclimate and lignin control of litter decomposition rates. Ecology 59:465-472

Melillo JM, Aber JD, Muratore JF (1982) Nitrogen and lignin control of hardwood leaf litter decomposition dynamics. Ecology 63:621-626

Monties B (1984) Dosage de la lignine insoluble en milieu acide: influence du prétraitement par hydrolyse acide sur la lignine klason de bois et paille. Agronomie 4:387-392

Moorhead DL, Lashermes G, Sinsabaugh RL (2012) A theoretical model of $\mathrm{C}$ - and $\mathrm{N}$-acquiring exoenzyme activities, which balances microbial demands during decomposition. Soil Biol Biochem 53:133-141

Nannipieri P, Gianfreda L (1998) Kinetics of enzyme reactions in soil environments. In: Huang PM, Senesi N, Buffle J (eds) Structure and surface reactions. Wiley, New York, pp 449-479

Palonen H, Thomsen AB, Tenkanen M, Schmidt AS, Viikari L (2004) Evaluation of wet oxidation pretreatment for enzymatic hydrolysis of softwood. Appl Biochem Biotechnol 117:1-17

Pianka ER (1970) On r- and K-selection. Am Nat 104:592-597

Resat H, Bailey V, McCue LA, Konopka A (2012) Modeling microbial dynamics in heterogeneous environments: growth on soil carbon sources. Microb Ecol 63:883-897
Sall S, Bertrand I, Chotte JL, Recous S (2007) Separate effects of the biochemical quality and $\mathrm{N}$ content of crop residues on $\mathrm{C}$ and $\mathrm{N}$ dynamics in soil. Biol Fertil Soils 43:797-804

Schimel JP, Weintraub MN (2003) The implications of exoenzyme activity on microbial carbon and nitrogen limitation in soil: a theoretical model. Soil Biol Biochem 35:549-563

Sinsabaugh RL, Carreiro MM, Repert DA (2002) Allocation of extracellular enzymatic activity in relation to litter composition, $\mathrm{N}$ deposition, and mass loss. Biogeochemistry 60:1-24

Šnajdr J, Cajthaml T, Valášková V, Merhautová V, Petránková M, Spetz P, Leppänen K, Baldrian P (2011) Transformation of Quercus petraea litter: successive changes in litter chemistry are reflected in differential enzyme activity and changes in the microbial community composition. FEMS Microbiol Ecol 75:291-303

Talbot JM, Yelle DJ, Nowick J, Treseder KK (2012) Litter decay rates are determined by lignin chemistry. Biogeochemistry 108:279-295

Vance ED, Brookes PC, Jenkinson DS (1987) An extraction method for measuring soil microbial biomass-C. Soil Biol Biochem 19:703-707

Voriskova J, Dobiasova P, Snajdr J, Vanek D, Cajthaml T, Santruckova H, Baldrian P (2011) Chemical composition of litter affects the growth and enzyme production by the saprotrophic basidiomycete Hypholoma fasciculare. Fungal Ecol 4:417-426

Wang GS, Post WM, Mayes MA, Frerichs JT, Sindhu J (2012) Parameter estimation for models of ligninolytic and cellulolytic enzyme kinetics. Soil Biol Biochem 48:28-38

Wickings K, Grandy AS, Reed SC, Cleveland CC (2012) The origin of litter chemical complexity during decomposition. Ecol Lett 15:1180-1188 